\section{'Appalachian Joy' is a Supernumerary, White-bracted Cultivar of Flowering Dogwood (Cornus florida) Resistant to Powdery Mildew (Erysiphe pulchra)}

\author{
Robert N. Trigiano ${ }^{2}$ \\ Department of Entomology and Plant Pathology, University of Tennessee, 2505 \\ E.J. Chapman Drive, 370 Plant Biotechnology Building, Knoxville, TN 37996
} Alan S. Windham
Department of Entomology and Plant Pathology, University of Tennessee,
5201 Marchant Drive, Nashville, TN 37211

\begin{abstract}
Mark T. Windham and Phillip A. Wadl ${ }^{1}$
Department of Entomology and Plant Pathology, University of Tennessee, 2505 E.J. Chapman Drive, 370 Plant Biotechnology Building, Knoxville, TN 37996
\end{abstract}

Additional index words. cultivar, disease resistance, Erysiphe pulchra, flowering dogwood, multiple bracts, powdery mildew

The wholesale nursery industry in Tennessee contributes more than $\$ 200$ million to the annual economy of the state. Flowering dogwood, Cornus florida, is a major income species of this industry and annual sales in Tennessee are in excess of $\$ 50$ million (Cappiello and Shadow, 2005). Two new fungal diseases that threatened the commercial production of dogwoods were reported in the last decade of the 20th century. During the early 1990s, dogwoods grown in Tennessee and other regions of the eastern United States (Daughtrey et al., 1996) were ravaged by an epidemic of dogwood anthracnose caused by Discula destructiva (Redlin, 1991), an introduced pathogen (Trigiano et al., 1995). This disease can cause the death of seedlings in as little as one growing season, whereas older trees may survive for several years. In 1998, the University of Tennessee introduced C. florida Appalachian Spring, the only documented cultivar with strong resistance to dogwood anthracnose (Windham et al., 1998). Chemical control of this disease is very costly. Since the mid-1990s, flowering dogwoods have been also afflicted with powdery mildew. Although more than one species of a powdery mildew pathogen was initially implicated in these epidemics (McRitchie, 1994; Ranney et al., 1994), the fungus Erysiphe (sect. Microsphaera) pulchra (syn. Microsphaera pulchra) is now recognized as the cause of annual epidemics in Tennessee (Klein et al.,

Received for publication 2 Feb. 2016. Accepted for publication 1 Mar. 2016.

This work was supported by the United States Department of Agriculture (grant no. 58-6404-1637) and AgResearch at the Tennessee Institute of Agriculture. ${ }^{1}$ Current address: USDA-ARS-U.S. Vegetable Laboratory, 2700 Savannah Highway, Charleston, SC 29414.

${ }^{2}$ Corresponding author. E-mail: rtrigian@utk.edu.
1998) and throughout the United States ( $\mathrm{Li}$ et al., 2009). Powdery mildew typically does not kill dogwoods, but renders the plants unsalable and also reduces flowering and growth (Li et al., 2009). to avert complete crop failure due to powdery mildew before 2005 was a comprehensive fungicide spray program that began in May and extended through September each year. Disease control costs for producing an acre of dogwoods soared to $\$ 1975$ annually (Li et al., 2009). Many small, one or two person-operated nurseries could not afford increased fungicide control costs as well as the additional costs for labor associated with a mandatory expanded disease management scheme. Because of unfavorable economics, many of the smaller dogwood nurseries subsequently ceased producing flowering dogwood.

There have been only a few controlled studies of powdery mildew resistance in flowering dogwood (Hagan et al., 1998; Windham et al., 2003) and most claims of resistance have been made antidotally in various publications, including a book by Cappiello and Shadow (2005) or in nursery catalogs. Similarly, there are many trees that are purported to have supernumerary bracts, but few are common in the nursery trade. Cultivars that combine resistance to powdery mildew and supernumerary bracts have not been reported (Table 1). To our knowledge, Appalachian Joy PP 18238 is the only cultivar of flowering dogwood in the nursery trade that is highly resistant to powdery mildew and has supernumerary bracts.

\section{Description of the Tree}

Cornus florida 'Appalachian Joy' is $\approx 4$ $5 \mathrm{~m}$ tall and broadly columnar after $10-15$ years of growth that has white (Green-White Group 157D; Royal Horticulture Society, 1990)
The only option that nursery operators had bracts with orange-red clefts (35B) (Fig. 1A and B). Bracts are stiff and overlap, and the number of bracts subtending inflorescences ranged from 4 to 8 , but averaged $5.6(n=44)$. Primary bract length is $3.8 \mathrm{~cm}$ and width is $4.4 \mathrm{~cm}(n=44)$. Inner (extra) bracts are generally smaller and are of variable size (Fig. 1A and B). Petals are yellow orange (14B), sepals are red (42D), and the number of flowers average 23 per inflorescence $(n=44)$. Leaves are yellow green (144A), bark is gray green (198A), fall foliage color is primarily red $(45 \mathrm{~B})$, but displays a variety of other colors (Fig. 1C and D). 'Appalachian Joy' is highly resistant to powdery mildew, but has not been evaluated for other diseases such as dogwood anthracnose.

\section{Origin and Disease Resistance Evaluation}

A search for flowering dogwood germplasm resistant to powdery mildew was started in 1994 as an alternative strategy to use of fungicides for disease prevention/control. Seedlings $(n=20,922)$ in an abandoned nursery field near Decherd, TN, and donated to the University of Tennessee were examined for signs and symptoms of powdery mildew in Aug. 1994 and 1995. From these examinations, we selected 84 plants that appeared to be free of powdery mildew. Disease free, dormant seedlings were harvested in the fall of 1995 and then subjected to high powdery mildew disease pressure in greenhouse studies for 2 years. Twenty seedlings were highly resistant to powdery mildew and the frequency for resistance in dogwood populations was estimated to be $\approx 0.1 \%$ (Windham and Witte, 1998). For replicated studies, the 20 powdery mildew resistant seedlings (PMRS) were grown and propagated vegetatively at the University of Tennessee Institute of Agriculture nursery greenhouses using a protocol that ensured optimum growth of the trees (Witte et al., 2000).

In 1998 and 1999, the level of resistance in the 20 PMRS was compared with the level of resistance found in C. florida 'Cherokee Brave', which has red bracts, and was the only cultivar at the time to have demonstrated resistant to powdery mildew, and 'Cloud Nine', a white-bracted, very susceptible cultivar (Hagan et al., 1998; Windham, 1996). Resistance levels for the group of 20 PMRS was statistically similar to level of resistance found in 'Cherokee Brave' (Windham and Witte, 1998). Statistical analysis comparing individual lines within the group of PMRS was not possible because only a single tree of each of the 20 genotypes was available during the 2 years. In this trial, the seedling that would be eventually named 'Appalachian Joy' was rated as 0 (no visible signs or symptoms of powdery mildew), whereas susceptible control trees averaged a score of 5.0 with greater than $50 \%$ of the foliage exhibiting disease symptoms and signs (see Table 2 for complete description of disease assessment scale values). In a replicated trial conducted from 2003 to 2009, disease resistance of 'Appalachian Joy’ was 
Table 1. Flowering dogwood (Cornus florida) cultivars and selections with either supernumerary bracts, resistance to powdery mildew, caused by Erisyphe pulchra or both.

\begin{tabular}{|c|c|c|c|c|}
\hline C. florida cultivars & Bract characteristics & $\begin{array}{l}\text { Powdery mildew } \\
\text { resistance }\end{array}$ & $\begin{array}{l}\text { Common } \\
\text { in trade }\end{array}$ & Reference \\
\hline Appalachian Joy PP 18,238 & Up to eight overlapping white bracts & High & No & This report \\
\hline Appalachian Spring & Four white bracts & Moderate to high & Yes & Trigiano et al., (unpublished) \\
\hline Eternal Dogwood PP 13,069 & Twelve to twenty white bracts & Unknown & No & Cappiello and Shadow, 2005 \\
\hline Jean's Appalachian Snow PP 13099 & Four white bracts & High & Yes & $\begin{array}{l}\text { Cappiello and Shadow, 2005; } \\
\text { Windham et al., } 2003\end{array}$ \\
\hline Karen's Appalachian Blush PP 13,165 & Four white bracts with pink margins & High & Yes & $\begin{array}{l}\text { Cappiello and Shadow, 2005; } \\
\text { Windham et al., } 2003\end{array}$ \\
\hline Kay’s Appalachian Mist PP 13,098 & Four white bracts & High & Yes & $\begin{array}{l}\text { Cappiello and Shadow, 2005; } \\
\text { Windham et al., } 2003\end{array}$ \\
\hline Mary Ellen & White "sparsely double bracts" & Unknown & No & Cappiello and Shadow, 2005 \\
\hline Miss Marion & White double bracts & Unknown & No & Cappiello and Shadow, 2005 \\
\hline Mr. Theodore & Four white bracts & "Considerable" & No & Cappiello and Shadow, 2005 \\
\hline Shadow's Plena & Up to eight white bracts & Unknown & No & Cappiello and Shadow, 2005 \\
\hline Welch's Bay Beauty & Up to seven pairs of white bracts & Unknown & No & Cappiello and Shadow, 2005 \\
\hline White Love PP 11,654 & Four white bracts & "Resistant" & No & Cappiello and Shadow, 2005 \\
\hline
\end{tabular}

${ }^{2}$ Not a true cultivar, but a collection of various supernumerary white-bracted flowering dogwoods.

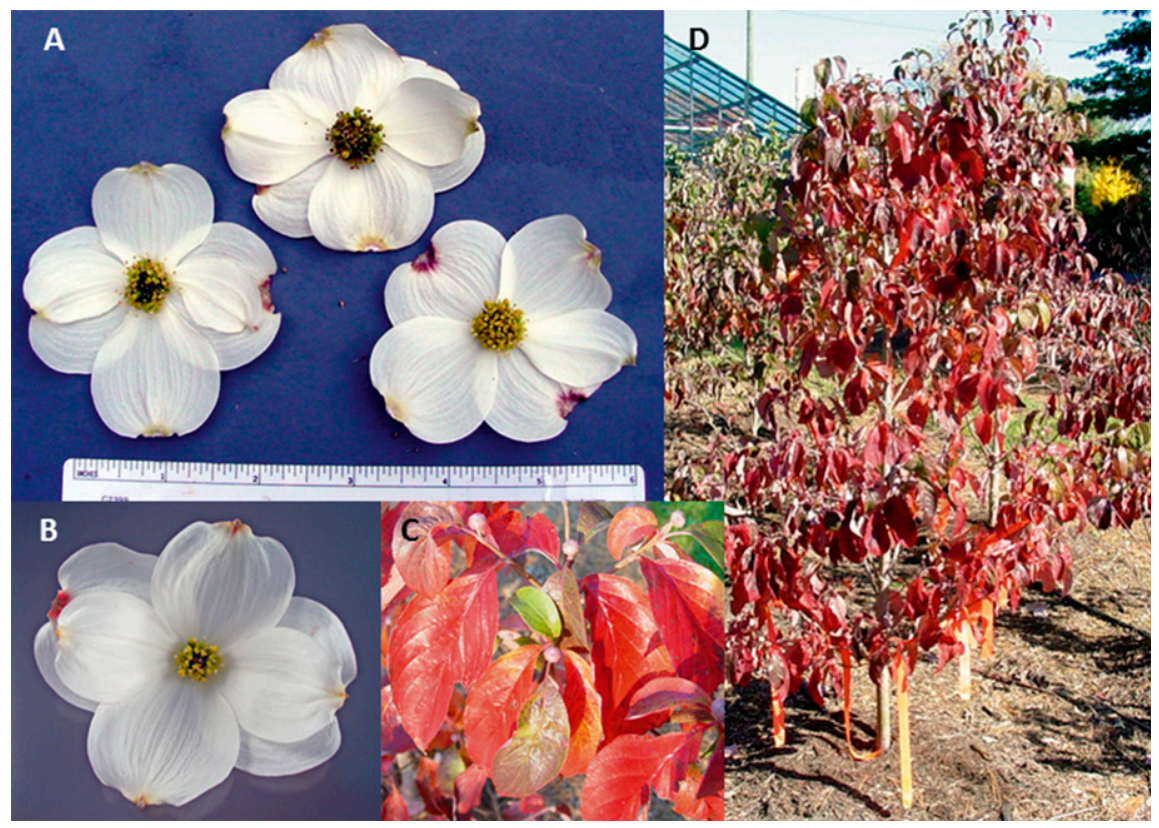

Fig. 1. Characteristics of Cornus florida ‘Appalachian Joy'. (A and B) Supernumerary bracts. (C and D) Fall foliage (September).

Table 2. Comparison of flowering dogwood (Cornus florida) cultivars for resistance to powdery mildew caused by Erispyhe pulchra. ${ }^{\mathrm{z}}$ Numbers represent the mean disease rating from 2003 to 2009.

\begin{tabular}{|c|c|c|c|c|}
\hline$\overline{\text { Cultivar }}$ & Block 1 & Block 2 & Block 3 & Mean rating \\
\hline Jean's Appalachian Snow ${ }^{x}$ & 0 & $\overline{0}$ & 0 & $0 \mathrm{a}$ \\
\hline Karen's Appalachian Blush & 0 & 0 & 1 & $0.3 \mathrm{a}$ \\
\hline Kay's Appalachian Mist ${ }^{x}$ & 0 & 1 & 0 & $0.3 \mathrm{a}$ \\
\hline Appalachian Joy ${ }^{\mathrm{x}}$ & 0 & 0 & 0 & $0 \mathrm{a}$ \\
\hline Cherokee Daybreak $^{\mathrm{w}}$ & 4 & 5 & 5 & $4.7 \mathrm{~b}$ \\
\hline
\end{tabular}

${ }^{2}$ Powdery mildew scores are based on the following scale: $0=$ healthy; $1=\leq 1 \%$ of foliage with signs or symptoms of powdery mildew; $2=\leq 10 \%$ of foliage with signs or symptoms of powdery mildew; $3=\leq 25 \%$ of foliage with signs or symptoms of powdery mildew; $4=\leq 50 \%$ of foliage with signs or symptoms of powdery mildew; and $5=>50 \%$ of foliage with signs or symptoms of powdery mildew.

${ }^{y}$ Means followed by the same letter are not significantly different according to Fisher's exact test at $P=0.05$.

${ }^{x}$ Powdery mildew resistance cultivar.

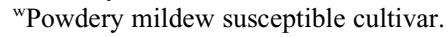

compared with resistance levels in 'Jeans Appalachian Snow' PP 13099, 'Karen's Appalachian Blush' PP13165, and 'Kay's Appalachian Mist' PP13098, all white cultivars that are highly resistant to powdery mildew (Windham et al., 2003), and 'Cherokee Daybreak', a white variegated cultivar that is highly susceptible to powdery mildew (Table 2). Powdery mildew was not observed on 'Appalachian Joy', whereas a low incidence $(<1 \%$ foliage affected) of powdery mildew was seen on 'Karen's Appalachian Blush' and 'Kay's Appalachian Mist' in some years. 'Cherokee Daybreak' consistently had over $50 \%$ coverage of foliage with powdery mildew, and during most years of the trial, almost $100 \%$ of the foliage showed signs and symptoms of powdery mildew. The disease rating for this cultivar was statistically $(P=0.011)$ different according to Fisher's exact test than all the powdery mildew resistant cultivars included in the trial. Powdery mildew on the leaves of 'Appalachian Joy' has occasionally been observed on trees planted in the landscape and stock blocks over the last 10 years, but only as small lesions affecting less than $2 \%$ of the foliage. Despite this very low level of disease incidence, 'Appalachian Joy' is the only documented white, multibracted flowering dogwood cultivar with strong resistant to powdery mildew.

\section{Genetic Analysis}

Genomic DNA from 'Appalachian Joy' and eight other cultivars of flowering dogwood, including powdery mildew susceptible and resistant, and a multibracted line, was isolated and compared with 17 polymorphic microsatellite loci using the 
Table 3. Genetic similarity indices for nine Cornus florida cultivars using 17 C. florida microsatellite loci. Higher values indicate less genetic similarity and lower values greater genetic similarity. ${ }^{z}$

\begin{tabular}{llllllllll}
\hline & AB & AJ & AM & AMN & AS & ASN & CB & CP & P \\
\hline AB & 0 & & & & & & & & \\
AJ & 0.50 & 0 & & & & & & & \\
AM & 0.62 & 0.71 & 0 & & & & & & \\
AMN & 0.76 & 0.74 & 0.85 & 0 & & & & \\
AS & 0.78 & 0.78 & 0.78 & 0.75 & 0 & & & \\
ASN & 0.59 & 0.65 & 0.71 & 0.74 & 0.94 & 0 & & \\
CB & 0.79 & 0.88 & 0.62 & 0.85 & 0.88 & 0.68 & 0 & \\
CP & 0.71 & 0.76 & 0.76 & 0.76 & 0.81 & 0.79 & 0.76 & 0 & \\
P & 0.62 & 0.62 & 0.76 & 0.68 & 0.88 & 0.62 & 0.82 & 0.82 & 0 \\
\hline
\end{tabular}

${ }^{\mathrm{z}}$ Code for cultivars: powdery mildew resistant cultivars: $\mathrm{AB}=$ Appalachian Blush; $\mathrm{AJ}=$ Appalachian Joy; $\mathrm{AM}=$ Appalachian Mist; AMN = Appalachian Morning; AS = Appalachian Spring; ASN = Appalachian Snow; $\mathrm{CB}=$ Cherokee Brave, powdery mildew susceptible; $\mathrm{CP}=$ Cherokee Princess, and powdery mildew susceptible with multiple bracts; $\mathrm{P}=$ Plena.

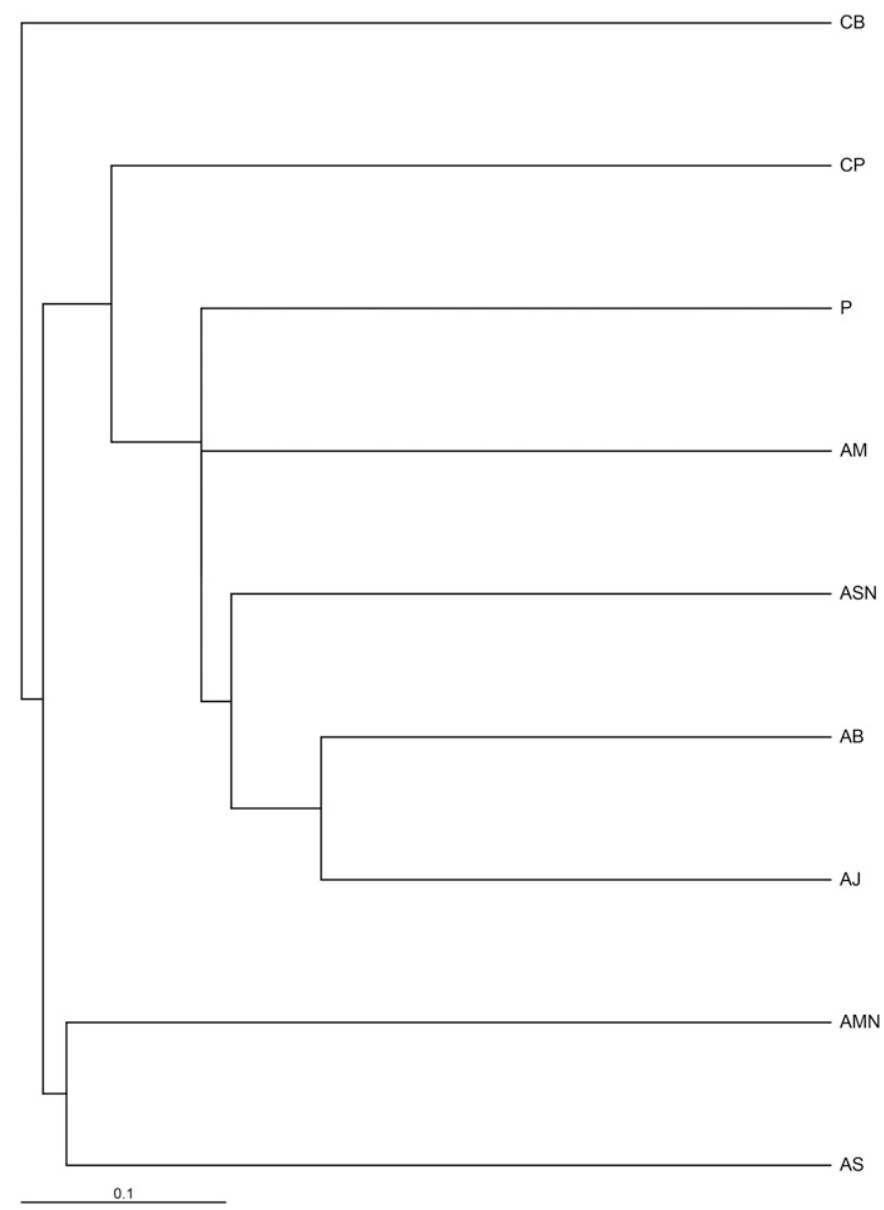

Fig. 2. Genetic analysis of Cornus florida cultivars with microsatellites. Dendrogram depicting the relationship between cultivars that are powdery mildew resistant [Cherokee Brave (CB), Appalachian Mist (AM), Appalachian Morning (AMN), Appalachian Snow (ASN), Appalachian Blush (AB), Appalachian Joy (AJ), and Appalachian Spring (AS)], powdery mildew susceptible [Cherokee Princess $(\mathrm{CP})$ ], and powdery mildew susceptible with multiple bracts [Plena (P)].

method of Wadl et al. (2008). A similarity index was generated by using Nei's coefficient (Table 3) and a dendrogram constructed using unweighted pair group method with arithmetic mean cluster analysis (Fig. 2). The DNA analyses demonstrated that 'Appalachian Joy' was most similar to 'Appalachian Blush', but was distinctly differentiated from all cultivars included in the study.
Ellington Agricultural Center (5201 Marchant Drive, Nashville, TN), and are available for propagation materials. Additional bulking of this cultivar via budding has been accomplished by selected nurseries. Please contact R.N. Trigiano (rtrigian@utk.edu) for additional information.

\section{Literature Cited}

Cappiello, P. and D. Shadow. 2005. Dogwoods. Timber Press, Portland, OR.

Daughtrey, M.L., C.R. Hibben, K.O. Britton, M.T Windham, and S.C. Redlin. 1996. Dogwood anthracnose: Understanding a disease new to North America. Plant Dis. 80:349-358.

Hagan, A.K., B. Hardin, C.H. Gilliam, G.J. Keever, J.D. Williams, and J. Eakes. 1998. Susceptibility of cultivars of several dogwood taxa to powdery mildew and spot anthracnose. J. Environ. Hort. 16:147-151

Klein, L.A., M.T. Windham, and R.N. Trigiano. 1998 Natural occurrence of Microsphaera pulchra and Phyllactinia guttata on two Cornus species. Plant Dis. 82:383-385.

Li, Y., M.T. Mmbaga, A.S. Windham, M.T. Windham, and R.N. Trigiano. 2009. Powdery mildew of dogwoods: Current status and future prospects. Plant Dis. 93:1084-1092.

McRitchie, J.J. 1994. Powdery mildew of flowering dogwood. Plant Pathol. Circ. No. 368. Gainesville, FL.

Ranney, T.G., L.F. Grand, and J.L. Knighten. 1994. Resistance of Cornus kousa taxa to dogwood anthracnose and powdery mildew. Proc. S. Nurserymen's Assoc. Res. Conf. 41:197-199.

Redlin, S.C. 1991. Discula destructiva sp. nov., cause of dogwood anthracnose. Mycologia 83:633-642.

Royal Horticulture Society. 1990. R.H.S. Colour Chart. Royal Horticultural Society, London, UK.

Trigiano, R.N., G. Caetano-Anollés, B.J. Bassam, and M.T. Windham. 1995. DNA amplification fingerprinting provides evidence that Discula destructiva, the cause of dogwood anthracnose in North America, is an introduced pathogen. Mycologia 87(4):490-500.

Wadl, P.A., X. Wang, A.N. Trigiano, J.A. Skinner, M.T. Windham, T.A. Rinehart, S.M. Reed, V.R. Pantalone, and R.N. Trigiano. 2008. Molecular identification key for cultivars and lines of Cornus florida and C. kousa based on microsatellite loci. J. Amer. Soc. Hort. Sci. 133(6):783-793.

Windham, M.T. 1996. Resistance to powdery mildew in flowering dogwood. Proc. S. Nurserymen's Assoc. Res. Conf. 41:197-199.

Windham, M.T., E.T. Graham, W.T. Witte, J.L. Knighten, and R.N. Trigiano. 1998. Cornus florida 'Appalachian Spring': A white flowering dogwood resistant to dogwood anthracnose. HortScience 33:1265-1267.

Windham, M.T. and W.T. Witte. 1998. Naturally occurring resistance to powdery mildew in seedlings of Cornus florida. J. Environ. Hort. 16:173-175.

Windham, M.T., W.T. Witte, and R.N. Trigiano. 2003. Three white-bracted cultivars of Cornus florida that are resistant to powdery mildew. HortScience 38:1253-1255.

Witte, W.T., M.T. Windham, A.S. Windham, F.A Hale, D.C. Fare, and W.K. Clatterbuck. 2000. American dogwoods. Dogwoods for American gardens. Agricultural Extension Service, The Univ. of Tennessee. PB1679-30-12/00. 